\title{
Islamization of Law of Evidence in Pakistan with Specific Reference to Testimony of a Woman
}

\author{
*Dr. Hafiz Muhammad Siddique \\ "Dr. Muhammad Atif Aslam
}

\section{ABSTRACT:}

The subject matter of any case contains many facts proved by anyone of the parties to have a decision in his favour from a court of law. The primary objective of the law of evidence is to prescribe the rules to prove the facts of the case assisting the court of law in any case. The Law of Evidence forms a foundation for administration of justice in every legal system. This is considered a system of rules for disputed questions of fact in judicial inquiries. This law determines and helps to enforce the liability or grant aright on the basis of facts presented in the court of law. Islamic Law of Evidence is manifest due to the Islamic System of administration of justice and it rules are framed by the Law giver on the basis of primary sources of Islamic Law whereas the rules of other evidence law are made by the people. The current paper discusses the process of Islamization in Islamic Republic of Pakistan. It focuses on the Law of Evidence that how it is Islamized. It also highlights the specific legal provisions of Pakistani Law of Evidence were Islamized and indicates the role of some other constitutional institutions of Pakistan in Islamization of Law of Evidence.

Keywords: Law of Evidence, Islamization, Pakistan, Qanun-e-Shahadat 1984.

\section{Introduction:}

Islam is not a religion that prescribes certain rituals only for Muslims but it also denotes a complete code of human conduct. Pakistan came into being on the basis of two nation theory and the Islamic ideology. The Quaid-e-Azam Muhammad Ali Jinah had attained a separate and independent country by his unabated, persistent and arduous strifes. He was having a determined contention for attaining a separate country with a view to provide Muslims of the sub-continent to live in all spheres of their lives in accordance with the teachings of Islam individually and collectively. This country came into existence as an Islamic State to bring Islamic Ideology into a reality. In all the Constitutions of this country including the last Constitution of 1973 complete name was described as "Islamic Republic of Pakistan". ${ }^{1}$ The substantial points of the Islamic Ideology of Pakistan are as under:

a. Sovereignty of Allah Almighty over the whole Universe.

b. Complete obedience and surrender of Muslims of the country to Allah.

c. Enable to live in this country individually and collectively in accordance with injunctions of Islam as laid down in the Qur'an and Sunnah of the Prophet (PBUH). ${ }^{2}$

*Assistant Professor, Faculty of Shari'ah \& Law, International Islamic University Islamabad. Email: hafiz.siddique@iiu.edu.pk

"Assistant Professor, Department of Islamic Learning, University of Karachi, Karachi. 
The process of Islamization of laws in Pakistan was started properly at the end of the 1970s under the leadership of Zia-ul-Haq. When he started the process of Islamization, he was actively supported by all the country but none was thinking on the issue that it is used for preservation of leadership in this country. It was directed by the leadership to Islamize a law so the people of this country spend their lives according to Islamic life style. For pursuance of this process of Islami-zation Muslim scholars, religious leaders, political parties and other Islamists parties were involved. He started a slogan that Pakistan was created on the basis of ideology of Islam and it's to be implemented in this country. ${ }^{3}$ He tried to Islamize all the laws existed at that time including Law of Evidence. He was having more concerns and observations with respect to Evidence law that was existed and implemented. In this regard, a letter was sent to Council of Islamic Ideology ${ }^{4}$ in 1981 emphasizing on the Islamization of Law of Evidence and indicating all those provisions repugnant to the injunctions of Islam. ${ }^{5}$ After thorough discussions and observations of the members of the Council agreed to prepare a new draft for law of Evidence instead of amending the former one law of evidence namely; "The Evidence Act 1872" because it contained many repugnancies. The draft of law of Islamic Law of Evidence was presented by the council ${ }^{6}$ and it was enacted as Qanun-e-Shahadat Order 1984 by the announcement and order of president of Pakistan $26^{\text {th }}$ October 1984. ${ }^{7}$ There are no specific and evident provisions in Law of Evidence (Qanun-e-Shahadat Order, 1984) regarding evidence of a woman but the issue of woman's testimony is in discussions of the religious scholars and Muslim jurists; either is it half to a man and what is the status of her evidence in criminal cases.

\section{Historical Perspective of Law of Evidence:}

Before the introduction of Indian evidence Act, there was no complete or systemic enactment on the subject. Within the presidency towns of Calcutta, Bombay and Madras, the Courts established by Royal Charter followed the English Rule of Evidence. The Common and Statute laws of England before 1726 were introduced in the presidency towns by the Charter of that year. Outside the Presidency towns, there were no fixed rules of evidence. Entire English law on the subject was never declared to be applicable to India by any statute. The law was vague and indefinite. The mofassil courts used to be guided by occasional decisions and a few rules regarding evidence and procedure contained in old Regulations made between 1793-1834, with the customary law although it did not assume any definite form.

The first attempt towards reform was the Act 10 of 1835 which was applicable to all courts in British India and dealt with the proof of the Acts of the Governor General in council. Between 1835 and 1853, a series of Acts were passed by the Indian Legislature, introducing some reforms for improvement of the Law of Evidence viz. Acts 10 of 1835, 20 of 1837, 9 of 1840, 7 of 1844, 15 of 1852, 19 of 1853. These Acts embodies with some additions, many of the reforms which were advocated by Bentham and introduced in England by Lords Brougham and Denman. ${ }^{8}$

The unsatisfactory state of the law was frequently commented on by the judges in 
their judgments. "The whole of Indian law of evidence" says Field, "might then have been divided into three portions, viz. one portion settled by the express enactment of the Legislature; a second portion settled by judicial decisions; and a third or unsettled portion and this by far the largest of the three, which remained to be incorporated with either of the preceding portions". ${ }^{9}$ Gradually, in the mofussil courts the belief gained ground that it was their duty to administer the English law of evidence and tendency towards a capricious administration of that law prevailed ${ }^{10}$.

Evidence Act of 1872 was the formal legislation on the subject passed into law in 1872, as Act 1 of 1872. The Act was based on English law of evidence with which the great mass of principles and rules of English law had been codified. ${ }^{11}$

\section{Law of Evidence in Pakistan :}

Until 1987, the Evidence Act, 1872 remained applicable in Pakistan. Under the claim of bringing it into conformity with the injunctions of Islam, the Government enforced the Qanun-e-Shahadat (Law of Evidence) Order, 1984. A great many legal experts agreed that very few amendments were required to bring the Evidence Act of 1872 into conformity with Islam. But according to others, the whole evidence was out of tune and in several places opposition to the words and spirits of the Qur'an and the Sunnah $^{12}$. The new Evidence Act is a lengthy document consisting of 166 sections. Very few changes have been made and they are generally of formal nature. The number and sequence of sections have however, been greatly changed. This has really distributed lawyers who were very much used to the old sequence. One writer calls it the Pakistani edition of English law, on the ground that there are no substantial changes and the law is basically the same under the old Act of $1872 .^{13}$

Some major changes are distinct in the Law of Evidence 1984 as follows:

\section{i. Preamble}

The preamble of Law of Evidence apparently indicating that this law must be brought in conformity with the teachings of Islam as: "Whereas it is expedient to revise, amend and consolidate the law of evidence so as to bring it in conformity with the injunctions of Islam as laid down in the Holy Quran and Sunnah.",14

\section{ii. Competence of a Witness}

The foundation of The Qanun-e-Shahadat Order, 1984 is on the Shari'ah principles as laid down in the Holy Qur'an and Sunnah of the Holy Prophet (PBUH). Pakistani Law of Evidence is not fully elaborating the terms and conditions of being a competent witness. Muslim Jurists have interpreted and discussed the qualifications of a witness in different matters. Pakistani Law of Evidence namely; Qanun-e-Shahadat Order, 1984 states regarding competent witness as:

"All persons shall be competent to testify unless the Court considers that they are prevented from understanding the questions put to them, or from giving rational answers to those questions, by tender years, extreme old age, disease, whether of body or mind or any other cause of the same kind." 15

This article signifies that a person to whom a court of law considers competent to testify as witness are capable to bear the testimony and criterion for such witnesses is 
that they understand the questions put to them and give rational answers. Law of Evidence does not permit the evidence of a witness who has been convicted for false evidence and perjury until repentance, however, court of law is to be satisfied as stated: "Provided that a person shall not be competent to testify if he has been convicted by a Court for perjury or giving false evidence. Provided further that the provisions of the first proviso shall not apply to a person about whom the Court is satisfied that he has repented thereafter and mended his ways.",16

The Court of Law has to determine the terms and condition of a competent witness according to the injunctions of Islam as stated in the last part of Article 3 of Qanun-eShahadat Order, 1984: "Provided further that the Court shall determine the competence of a witness in accordance with the qualifications prescribed by the injunctions of Islam as laid down in the Holy Qur'an and the Sunnah for a witness, and where such witness is not forthcoming the Court may take the evidence of a witness who may be available.

Article 3 of this order, 1984 lays down two tests of a witness for his competence; first one is the capability of a person to understand the questions and give rational answers. Here issue of a child testimony also arises because in court of law particularly in civil cases the testimony of a child is accepted. ${ }^{18}$ Secondly, this article indicates that court of law has to determine terms and conditions being a trustworthy witness in accordance with the commands of Shari'ah as prescribed in the Holy Qur'an and Sunnah of the Holy Prophet (PBUH) but the court is advised through the law that rights of the parties must be protected and where a competence witnesses are not available then the evidence of all available witnesses is to be recorded. However, a man who is sentenced of perjury and false testimony is not considered a reliable witness until the court is satisfied with his repentance and thinks competent witness. This proviso is based on the verses of Surah Al-Noor as Almighty Allah states: "And those who accuse honourable women but bring not four witnesses, scourge them (with) eighty stripes and never (afterwards) accept their testimony - They indeed are evil-doers - Save those who afterward repent and make amends. (For such) lo! Allah is Forgiving, Merciful.",19 Justic Khalil-ur-Rahman explains that if a person is not understanding the question and unable to give a reasonable answer is considered a incapable person; whatever the reason may be of his deficiency such as disease, old age, unconsciousness and insanity etc. ${ }^{20} \mathrm{He}$ further elaborates that the evidence of a lunatic is accepted when he gives the rational answers to the question put to him. He also applies this principle on a person who is partially insane, when he is in the state of normality, he is to be graded a competent witness. ${ }^{21}$ Now we observe the different observations and reservations of contemporary writers regarding some provisions of Qanun-e-Shahadat Order 1984 as Rashida Patel comments:

"There is a serious danger to the rights of the witnesses by keeping the door wide open for the hundreds of courts in Pakistan to determine the competence of witness. And, by allowing the several courts to decide what is or is not in accordance with the injunctions of Islam". ${ }^{22}$ 
Mehdi further explains that it depends on judge whether he wants to consider two female witnesses equal to one male witness. Thus the new law of evidence not only reduces the women to the position of legal destitute but also opens the floodgates to unending controversies about the interpretation of Qur'an ic injunctions because of its vagueness and ambiguity. ${ }^{23}$ In this regard Justice (Rtd.) A.R. Changea remarked: "I would like to add that the qualifications as required by the third proviso of article 3 , to determine the competence of witness, should have been prescribed and should not have left for discussion by each judicial officer. I am afraid it would open a Pandora's Box". ${ }^{24}$

Presumption of legitimacy is another aspect in which the Qanun-e-Shahadat Order 1984, has made important changes. Section 112 of the Evidence Act of 1872 has been replaced by the section 128. According to the section 112 of the Evidence Act, there was no minimum period of gestation and the maximum period was 280 days. Under the Evidence Act, 1984, the minimum period is 6 months and the maximum period is two years. Muslim classical law is controversial concerning the maximum period of gestation. The 1984 Act has adopted the view of Hanafi School of thought. Firstly, this is in conflict with modern science and secondly, it could start endless controversies among different Muslim sects in Pakistan. ${ }^{25}$

\section{iii. Number of Witnesses}

Qanun-e-Shahadat Order 1984 evidently describes that the number of witnesses in any dispute of controversy will be determined in conformity with the principles of Islam according to the nature of the case as states:

"The number of witnesses required in any case shall be determined in accordance with the injunctions of Islam as laid down in the Holy Qur'an and Sunnah. "26

It further expresses and explains that that unless otherwise provided in any law relating to the enforcement of $H u d \bar{u} d$ or any other special law as under:

a. "In matters pertaining to the financial or future obligations, if reduced to writing, the instrument shall be attested by two men, or one man and two women, so that one may remind the other, if necessary, and evidence shall be led accordingly" ${ }^{\text {, }}$; and

b. "In all other matters that court may accept, or act on the testimony of one man or one woman, or such other evidence as the circumstances of the case may warrant."28 In this article testimony of a single woman is not considered a reliable in financial matters, her capacity as a principal party in financial transactions has been put in doubt by this provision. This may make it increasingly impossible for women to enter into such contracts independently.

Rashida Patel points out that the provision has belittled the status of several women working as administrators, bankers, lawyers and judges, for they often have to request their male clerks and peons to attest documents drawn up by them. ${ }^{29}$ This provision is claimed to be based on a verse 282 of the Holy Qur'an that has interpreted in different ways by the Muslim Jurists.

All the Muslim jurists agreed that in Zina and Qazf four witnesses are must but in 
rights, dealings, transactions and other criminal matters two men or one man and two women. Shafi' 'iyyah make another difference in civil matters especially which, is not a financial transaction e.g. Nikah, two men are must. Zahiris allow women in all categories including Hudūd but two women are equal to one man. There are some other evidences from those we can say that one women or one man is enough to prove a right or offence. Imam Ibn-e-Qayyim says that the intent of Lawgiver is to protect the rights with any kind of evidence and the testimony of one man, if he is just cannot be rejected but the fact is when it is clear that a witness is just then decide a case on his testimony as The Holy Prophet (PBUH) accepted the testimony of Abu Qatadah and made admissible the testimony of Khuzaima alone. ${ }^{30}$ Besides this there are evidences which indicate that only on circumstantial evidences we can decide the case. $^{31}$ The Muslim jurists unanimously agreed on the issue that the evidence of women is sufficient in all matters relating to themselves or in matters not relevant to men such as the evidence of new born showing signs of life at birth. ${ }^{32}$

Evidence stands a vital position and weighing scale in the judicial system for administration of justice. It may be measured in numerous methods such as confessional, circumstantial, writing, oral, and documentary. Testimony based on the facts presented before a judge in a court of law by any person with respect to any controversy or dispute has been observed by him personally. ${ }^{33}$

In Islamic Law of Evidence, testimony of a woman is considered half to a man on the basis of a verse 282 of Surah Al-Baqarah of the Holy Qur'an as Almighty Allah states: "O you who believe! When you contract a debt for a fixed period, write it down. Let a scribe write it down in justice between you. Let not the scribes refuse to write as Allah has taught him, so let him write. Let him (the debtor) who incurs the liability dictate, and he must fear Allah, his Lord, and diminish not anything of what he owes. But if the debtor is of poor understanding, or weak, or is unable to dictate for himself, then let his guardian dictate in justice. And get two witnesses out of your own men. And if there are not two men (available), then a man and two women, such as you agree for witnesses, so that if one of them (two women) errs, the other can remind her.

In Islamic Law, there are two questions under discussion:

1. Either the testimony of a woman is half to a man?

2. Either the testimony of a woman is accepted in Hudud and Qisas cases?

First question is on the basis of verse, 282 of Surah Al Baqrah as interpreted by the Muslim Jurists that two woman's testimony is equal to a man. ${ }^{35}$

\section{Evidence of a Woman in Hudūd and Qisas Cases}

The Orthodox Muslim Jurists have diverse opinions on the issue of woman's testimony to be accepted in Hudūd and Qisas cases. This is the unanimous view of the majority from all schools of thought that a witness must be a male in such cases and woman's testimony is inadmissible in Hudūd and Qisas cases at all, whether she tenders it alone or along with men. ${ }^{36}$ But there are some other classical Muslim jurists like Imam Ibne-Hazm, Imam Ibn-e-Taymiyya, Imam Ibn-e-Qayyim and some contemporary Muslim 
scholars like Mahmood Ahmad Ghazi, Mawlana Umar Usmani have the opinion that a woman's testimony is accepted in all types of cases including Hudūd and Qisas. ${ }^{37}$

\section{Discussion on the Evidence of a woman in Pakistan after Qanun-e-Shahdat Order 1984}

One step towards Islamization of civil law that created considerable reaction among educated women was the Draft Law of Evidence passed by the Shoora (Parliament) in February 1983. The main controversy surrounding this draft concerned the number of witnesses necessary to establish evidence in a court of law. As reported in the newspapers, the draft law stipulated that the number and particulars of the witnesses would be in accordance with the Holy Qur'an and Sunnah the details of which are as under: "In Hudūd cases, according to the Hudüd Ordinance. In Qisas (Retaliation) cases according to the capital punishment and Diyat (blood money) Ordinance. In other matters, two men or one man and two women. If the said witnesses are not available, the court shall decide on the evidence of one woman or such other evidence as circumstances may be available." 38

In other words, women would have been completely barred from giving evidence in Hadd cases, i.e., cases of murder, theft, Zina, and drinking. Otherwise their testimony would be worth half a man's testimony. ${ }^{39}$ President Zia sent the bill to the Law Division for "final approval" so it would be ready for implementation in the Qazi courts, which were supposed to start functioning on an experimental basis in March 1984. Without the enactment of the Law of Evidence, Qazi courts would not be able to function properly. The Law Division was said to have made certain amendments as recommendations submitted to the President by the Chief Justice of the Shariah Court. ${ }^{40}$

The symbolic power of making the legal evidence of one woman equal to half the evidence of one man led to many protests both before and after the draft Law of Evidence passed by the Majlis-i-Shoora (Parliament). Several women's groups made public statements against legal discrimination on the basis of gender. On February 12, 1983, a small group of women lawyers and other interested women met in front of the High Court building on the Lahore Mall to protest the draft Law of Evidence. ${ }^{41}$ Reaction to the protest and the police measures took two forms. The APWA (All Pakistan Women Association) and other women's groups, as well as a few maledominated groups such as the Lahore High Court Bar Association, condemned the police action. On the other hand, a great many articles in both Urdu and English dailies branded the demonstration "sacrilegious". According to the Pakistan Times, about 100 renowned ulama described women's protest against the Law of Evidence as a proclamation of war against God's commands. ${ }^{42}$

The major strategy used by all parties to support positions for and against the draft law was to cite the Qur'an. Several attempts were made to claim that women lawyers were not competent to interpret the Qur'an. One article declared, "It is surprising that a small group of westernized women who cannot even read Arabic consider themselves qualified to interpret the Holy Qur'an." ${ }^{43}$ Dr. Israr Ahmad, well-known for his controversial remarks, commented that "the Qur'anic provisions with regard to women's posture vis-a-vis their evidence is clear and that two of them are equal to one 
man. This is a bitter pill which a modem and educated woman will have to swallow in an Islamic society." ${ }^{44}$ Not ready to start swallowing yet, the Islamabad branch of the WAF planned to start weekly classes in Arabic and Qur'anic studies, for "women must be prepared to fight their own battles." ${ }^{45}$ On the contention that since woman's evidence is half that of a man, hence she is inferior to men, he argues that:

"The quality of evidence is not dependent on the sex of the witness but the quality of observation, retention and delivery. This differs from person to person. No superiority in this behalf can be presumed for any sex.",46

The Law of Evidence (Qanun-e-Shahadat) promulgated by a Presidential order in October 1984 gave women equal voice in giving legal evidence except for financial transactions. This significant change in the draft law passed by the Shoora more than a year earlier came from a President's Commission on the Law of Evidence. Predictably, those women's organizations fighting for equal civil rights for both genders criticized the new law, calling it "vaguely and incompletely drafted." Lack of clarification in the law as to the meaning of the phrase "matters pertaining to financial obligations" was seen as a particular handicap for women engaged in business. The WAF (Democratic), a splinter group, joined the Punjab Women Lawyers Association and the Anjuman Behbood-i-Khawateen in calling for a boycott of all government functions, but this effort failed. ${ }^{47}$

A number of arguments were put forward showing that the proposed Law of Evidence in fact was not the only acceptable evidence law in Islam. Members of the Women's Action Forum and the Pakistan Women Lawyers Association contested that there is only one instance in the Qur'an, verse 282 (Surah Al-Baqra), in which two women are called to testify in the place of one man. This is in a specific financial arrangement, and the role of the second women is to remind the first on points she may have forgotten. In numerous other verses, men and women are referred to as being equal in matters of witness. ${ }^{48}$ Critics also note that the testimony of Hazrat Khadija, the Prophet's (PBUH) first wife, which asserted that Mohammad was the Prophet (PBUH) of God, made her the Prophet's (PBUH) first disciple. On the single testimony of Hazrat Aisha (another of the Prophet's (PBUH) wives), hundreds of Ahadith (sayings, actions, and states of the Prophet (PBUH)) have been verified. In addition, they point out that a rigid interpretation of the Qur'an such as would support the Law of Evidence (i.e., meaning "male" whenever the generic word "man" was used) would exclude women from being members of the religion. As to the exclusion of women's evidence as inadmissible in Hudüd cases it has been charged that the sole evidence of Hazrat Naila, the wife of Usman (the third Caliph), was accepted by the Prophet's (PBUH) companions regarding the guilt of Usman's murderer. Opponents also argue that criteria for witnesses, as stated in the Qur'an is possession of sight, memory, and the capability to communicate. As long as witnesses have these, be they men or women, their testimony should be equally weighed. The interpretation that was finally decreed on October 27, 1984, as the Law of Evidence restricts the testimony of two women being equal to that of one man only to financial cases; otherwise, it is left up 
to the discretion of the judge.

\section{Evidence of Women in Muslim Countries:}

An international Conference on the subject of "Islamic Laws and Women in the Modern World" was held in Islamabad on 22-23 December, 1996. The main theme of the Conference was how Islamic laws have dealt with the problems of the Muslim women in the modern world. The changing social, economic and legal conditions in Muslim societies, particularly after they developed into modern independent nationstates having power to legislate on their own, posed a challenge of reform in the status and role of women in these societies. Muslim jurists faced these challenges and dealt with these problems with diverse approaches. The participants from various countries of the Muslim world also highlighted and discussed the issues relating to the status of testimony of women in Islam and enforcement of laws in their respective countries on the subject. Position of legislation on law of evidence with particular emphasis on the testimony of women in different Muslim countries is as follows:

Bangladesh: Evidence based on English common law for two hundred years.

Egypt: a. Two women/one man, only impersonal status law.

b. In all courts in Egypt, equal evidence of men and women.

Iran: a. No witnesses are needed for marriage; however, the marriage should be registered.

b. Qualification rather than the number of those given evidence has precedence

c. In divorce only two male witnesses are needed

d. Judges have enough power to take judgments on their own

e. Evidence of men alone in penal code is at the discretion of judges.

Malaysia: a. If the women appear in court to give Bayyinah (evidence) then the formula does not apply.

b. If a woman appears to give shahadat, then formula is followed. All the Muslims can give Shahadah or Banniyah if they have certain qualities.

c. Testimony of a non-Muslim is accepted in the court.

d. Dispute between spouses is admissible as Banniyah.

Pakistan: a. Competency of a witness is determined by the court in accordance with the injunctions of Islam. There in no reported case of any female being excluded from giving evidence on the basis of competency.

b. For financial or future obligations, if reduced to writing, the instruments are to be attested by two men or one man and two women.

c. For awarding the punishment of Hadd, the evidence of women is not admissible.

Tunisia \& Turkey: Emphasized the equality of all citizens before the law. Men women are equal; both can be witnesses and judges. ${ }^{49}$

\section{Summary of Deliberations on Evidence in the Conference}

1. Interpretation of Islamic injunctions regarding the evidence of two women visà-vis one man is seen as discriminatory, especially for the women in financial institutions.

2. Legislators should realize that the times have changed, and the whole position 
of women has changed. Thus modification is needed.

3. A response to this concern is that one should put contracts in writing, according to the Qur'an. The two women-one man formula applies to oral contracts only.

4. One may add that the issue here is not the formula only, but what is beyond the formula. As it has been used in some circles to stigmatize women with inferiority. 5. Another argument is that the Prophet (PBUH) judged on the basis of one evidence: "Al-Banniyah ala al-Mudda'I wal-Yamin ala-man ankara". There should be two witnesses, but not necessarily one man and two women.

6. Tunisia and turkey emphasized the equality.

7. Only nine verses in Qur'an deal with this issue, of these, eight references treat both sexes equally. ${ }^{50}$

\section{Conclusion:}

Islamic Republic of Pakistan was created with the name of Islam and the main purpose was to attain an independent country for Muslims. Quaid-e-Azam was very clear about this manifesto and he succeeded in 1947. After him, other leaders of this country came up with their own thought and ideas of reforming Islam. The proper process of Islamization of Laws was started in the era of Zia-ul-Haq. He started introducing classical Islamic Law with the support of all religious groups and political parties. After partition, Evidence Act was applied and implemented as it was practiced before partitions. President Zia-ul-Haq sent a letter to Council of Islamic Ideology for examining an Evidence Act 1872 and the CII has drafted a new Law of Evidence and it was enacted as Qanun-e-Shahadat Order 1984 with the approval of President. The preamble of this law clearly expressed that it could be in accordance with the injunctions of Islam as laid down in the Holy Qur'an and Sunnah of the Holy Prophet (PBUH). Article 3 of this QSO 1984 prescribes the qualification for being a witness and it also prescribes according to the teachings of Islam. Article 17 denotes the number of witnesses and they also must be as laid down in the verses of the Holy Qur'an and Sunnah of the Holy Prophet (PBUH). The testimony of a woman is not admissible in Hudud and Qisas cases according to the Classical jurists but contemporary Muslim Jurists including Imam Ibn Taymiyyah make it admissible. But all the classical Muslim jurists unanimously settled and established an opinion that testimony of a woman is half to a man but contemporary jurists accept her testimony but Hadd punishment is not implemented due to doubt in the evidence of a woman but offender is punished and nature of punishment is to be determined by a judge of court of law.

\section{References \& Notes}

${ }^{1}$ The Constitution of Islamic Republic of Pakistan 1973, Article: 1.

${ }^{2}$ Ibid., Preamble.

${ }^{3}$ Ibid., Article: $227-28$.

${ }^{4}$ This is a Constitutional Institution constituted to check all the existing laws and bring in conformity with Islamic injunctions. See: The Constitution of Islamic Republic of Pakistan 1973, Article: 227-28. 
${ }^{5}$ Council of Islamic Ideology, Annual Report, 1981-82, 58

${ }^{6}$ Ibid.

${ }^{7}$ This law was approved in the President's Order No. 10 of 1984.

${ }^{8}$ Act 2 of 1855 contained valuable provisions, designed as supplementary to and corrective of the English Law, although all its provisions presuppose the existence of that a body of law upon which those reforms were engrafted yet it was authoritatively laid down that English law of Evidence was not the law in the mofussil.

${ }^{9}$ Sarkar's Law of Evidence, 1-4

${ }^{10}$ Because the English law was based on its social and legal institutions of England was not applicable here in entirety and a complete knowledge of English law could then be hardly expected from the judges.

${ }^{11}$ Sarkar's Law of Evidence, 1-4

${ }^{12}$ See for detail; Qanun-e-Shahadat Order 1984, Articles: 3 \& 17.

${ }^{13}$ Rubya Mehdi, The Islamization of the Law in Pakistan, 147.

${ }^{14}$ The Qanun-e-Shahadat Order 1984, Preamble.

${ }^{15}$ The Qanun-e-Shahadat Order 1984, Article: 3. See also: M. Mahmood, Qanun-e-Shahadat Order, 1984, (Lahore: Pakistan Law times Publications, 2007), 129.

${ }^{16}$ Ibid.

${ }^{17}$ Ibid.

${ }^{18} 1985$ PSC 1407

${ }^{19}$ The Holy Quran, Al-Noor: 4, 5

${ }^{20}$ Justic Khalil-ur-Rahman,Qanun-e-Shahadat Order, 1984, (Lahore: PLD, Publications), vol.1: 57

${ }^{21}$ Ibid.

${ }^{22}$ Rashida Patel, Islamisation of Laws in Pakistan, (Karachi: Faiz Publishers, 1986), 147-48

${ }^{23}$ Rubya Mehdi, The Islamization of the Law in Pakistan, (Curzon Press, 1994), 147.

${ }^{24}$ Ibid., 148

${ }^{25}$ Ibid., 147

${ }^{26}$ The Qanun-e-Shahdat Order 1984, Article: 17 (1)

${ }^{27}$ Ibid., Article: 17 (2) (a)

${ }^{28}$ Ibid., Article: 17 (2) (b)

${ }^{29}$ Rashida Patel, Islamisation of Laws in Pakistan, (Karachi: Faiz Publishers, Pakistan,1986), 149.

${ }^{30}$ Ibn-e-Qayyim, I 'lamul Muwaqqe in, vol.1, 100-104.

${ }^{31}$ Ibid., vol.1, 130

${ }^{32}$ Ibn-e-Hazm, Al Muhalla, vol. 9, 399.

${ }^{33}$ H.A.R. Gibb, J. H. Karamers and others, The Encyclopedia of Islam, (Leiden: E. J. Brill \& London: Luzac \& Co., 1960), s.v. "Shahādah".

${ }^{34}$ The Holy Qur'an, 2: 282.

${ }^{35}$ See Abu Al-Hassan Ali Ibn Abi Bakr Al Marghinani, Al Hidayah, (Karachi: Idarat Al-Quran wa Al-,,Uloom Al-Islamiyyah, Pakistan), 5: 417. Ibn-e-Rushd, Bidayat ul Mujtahid, (Beirut: Dar ul Fikr, nd.),2:48. Abu Zakariyya Muhyuddin Ibn Sharaf, Al-Nawavi, "Al-Majmoo' Sharh Al-Muhadhab", (Dar Al-Fikr) 20:252. Abdullah Ibn Ahmad Ibn Qudamah , Al Mughni, ( Beirut: Dar Al-Fikr ,1984), 10:155 
${ }^{36}$ Ibid

${ }^{37}$ See for detail: Abu Muhammad Ali Ibn Ahmad Ibn Hazm, Al Muhalla, (Beirut: Dar Al Afaq Al Jadidah, nd.), 9: 399. Abu Abdullah Muhammad Ibn Abi Baker Ibn Al-Qayyim, Al-Turuq-AlHukmiyyah, (Egypt: Dar Al-Madni, nd), 170. Abu Al-Qasim Jafir Ibn Al-Hassan, Sharai Al Islam, (Najaf: Al-Ishraf, 1969), 4:136. 55. Mahmood Ahmad Ghazi, "Hudud aur Qisas key Muqaddamat min Awratun ki Gawahi ”, Fikr-o-Nazar (Jan-Mar,1993), 18. 56. Mawlana Umar Ahmad Usmani, Fiqh-ul-Quran, (Karachi: Idarah Fikr Islami, 1984), 3:118. 57. Javed Ahmad Gamidi, Burhan (Lahore: Al-Mawrid, nd.), 33. 58. Maulana Muhammad Taseen, "The Testimony of women in the light of Qur"eanand Hadith” Fikr-o-Nazar, (Jul-Sep, 1990), 154.

${ }^{38}$ The Law of Evidence was signed by President Zia on October 26, 1984, "to the thunderous applause of the Shoora." (Pakistan Times Overseas Weekly, August 5, 1984) See also "Qanoon-iShahadat, "Salient Features," Dawn, March 5, 1983, p. 3, also, Ashraf Hashmi, "Shoora Prorogued: Evidence Law with Substituted Clause Passed," The Muslim, March 4, 1983.

${ }^{39}$ Yameema Mitha, "WAF Meeting: Women Reject Draft Law of Evidence" The Muslim, Feb:10, 1983

${ }^{40}$ In January 1984, the government announced that women would be appointed as qazis to newly established women's courts, where women litigants could choose women lawyers to serve them.

${ }^{41}$ In early February 1984, the Lahore WAF group announced a march on the Lahore High Court on February 12 to commemorate the episode of the previous year. A group of women protesting the Draft Law of Evidence did march on the High Court, but no untoward incident occurred. The police merely stood by and watched. It was a peaceful demonstration, but the interesting point was the treatment by the press. The Muslim, published in Islamabad, reported the affair with about four inches of space on an inside page under the caption "Women's Rally in Lahore"; Dawn, published in Karachi, gave it about eight inches of space, plus a photograph of about $5 \times 8$ inches showing a group of young women carrying placards, with the caption "Lahore Women Demonstrate" while the Pakistan Times, published in Lahore, the scene of the demonstration, totally ignored the whole affair.

${ }^{42}$ Pakistan Times, February 18, 1983

${ }^{43}$ N. A. Khwaja, "Women's Rally: The Slogan and the Motive," The Pakistan Times, 18 Feb:1983

${ }^{44}$ Dr. Israr Ahmed, an official of Pakistan Television publicly stated that all employed women should be pensioned off and return to their homes and live in purdah

${ }^{45}$ Fauzia Rafiq, "Evidence Act a Forced Compromise," The Muslim, 10 March, 1983, 3

${ }^{46}$ Khalid M. Ishaque, "Note on Proposed Law of Qisas and Diyat", 14

${ }^{47}$ Pakistan Times Overseas Weekly, 4 November, 1984, 5

${ }^{48}$ See, for example, The Holy Qur'an, Surah Al-Noor: 6 -9

${ }^{49}$ International conference on Islamic Laws and Women in the Modern World, (Islamabad: Giant Forum, 1996), 127, 128

${ }^{50}$ Ibid., 145-146

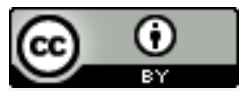

This work is licensed under a Creative Commons Attribution 4.0 International License. 